\title{
Deans in Canadian Universities: A Managerial Perspective ${ }^{1}$
}

\author{
BERNARD GARNIER*
}

\begin{abstract}
The main objective of this article is to investigate the dean's roles and functions from a managerial perspective. It reports the findings of an empirical study conducted in selected Canadian universities which tried to identify the dimensions of an effective deanship and find correlates of effective performance for a dean. More specifically, this article focuses on the following variables and their relationships: dean's managerial effectiveness, dean's conflict-handling modes, length of time the dean has served in office and size of the dean's faculty.
\end{abstract}

\section{RÉSUMÉ}

Cet article a pour objectif principal d'examiner les fonctions et les rôles de doyen d'université dans une perspective managériale. L'article s'appuie sur une étude empirique qui fut réalisée à partir d'un échantillon d'universités canadiennes. $L$ 'enquête cherchait à identifier les principales dimensions et facteurs qui constituent et influencent l'efficacité administrative des doyens d'université. Cet article s'intéresse, d'une façon plus spécifique, aux variables suivantes et à leurs relations entre elles: efficacité managériale des doyens, modes de gestion des conflits utilisés par les doyens, le temps que les doyens ont servi dans leurs fonctions, la. taille de la faculté des doyens.

\section{INTRODUCTION}

The environment of Canadian universities has changed dramatically in the last few years. Canadian universities are now in a difficult situation and the future appears, at best, uncertain. The major problem facing institutions of higher education is financing. Since universities derive approximately $70 \%$ of their revenues from their provincial governments, they are deeply affected by the budgetary restraint programs recently adopted by provincial governments in Canada.

* Département de management, Faculté des sciences de l'administration, Université Laval 
The pressing demands of governments and of the general public for more accountability have forced universities to achieve a more effective and efficient management of their financial and human resources at all levels of operation: central administration, faculties, departments and ancillary services. It is this researcher's belief that the deanship is a key element in the university system and that deans as chief executive officers of their faculties are very much instrumental to university effectiveness and efficiency as a whole.

Unfortunately, little is known about the deanship seen from an administrative or managerial perspective. What are the different dimensions of an effective deanship? What are the main correlates of an effective performance for a dean? What conflict-handling skills should a dean possess and use in his increasingly difficult dealings with senior academic officers, department chairpersons and faculty members? Deans themselves are not very helpful in providing answers to these difficult questions, rather as if they do not wish to dissipate the traditional folklore surrounding their jobs. Alfred Kahn, for instance, reflecting on his functions as a dean at Cornell University, irreverently concluded that "a dean is, to a faculty, as a hydrant is to a dog". Father Damian Fandal of the University of Dallas, drawing on his own experience of the deanship, facetiously stated a survival rule for academic deans: "1. Hide! 2. If they find you, lie!".

The literature and research on the academic deanship are not very explicit regarding the managerial functions of deans. The literature of higher education does not offer a comprehensive framework for assessing the dean's performance of managerial functions. Empirical research on the academic deanship is rather abundant but mainly descriptive, biographical, and not management-oriented (Konrad, 1980). The main objective of this article is to look at the dean's roles and functions from a management point of view and to test if this perspective is helpful in improving the administrative effectiveness of the academic dean. More specifically, this article will focus on the following variables and their relationships: dean's managerial effectiveness, dean's conflict-handling modes, length of time the dean has spent in office and size of the dean's faculty.

\section{FORMULATION OF RESEARCH HYPOTHESES}

In this article, four main research hypotheses are tested. They involve variables which have a significant impact on the managerial functions of the academic deanship. For each hypothesis, we discuss the theoretical or empirical rationale supporting its formulation. The following relationships between variables will be investigated.

Hypothesis 1: Dean's modes of handling conflict and dean's managerial effectiveness.

Hypothesis 2: Dean's time in office and dean's managerial effectiveness. 
Hypothesis 3: Dean's time in office and dean's modes of handling conflict.

Hypothesis 4: Dean's faculty size and dean's managerial effectiveness.

\section{Hypothesis 1: Relationships Between Dean's Conflict-Handling Modes and Dean's Managerial Effectiveness}

Blake and Mouton (1964) have developed a model which identifies five ways of dealing with conflict. They are: (1) Problem-Solving, (2) Forcing, (3) Compromising, (4) Smoothing and (5) Avoiding. Writers on conflict management, including Blake and Mouton (1964), Lawrence and Lorsch (1969), Burke (1970) and Filley (1975) classify Problem-Solving as a "Win-Win", strategy, that is, both parties involved in a conflict situation achieve their objectives by an open exchange of information about the conflict as the parties see it and a working through of their differences to reach a solution that is optimal to both.

Forcing is mainly seen as a "Win-Lose" strategy, in which one party achieves his own objectives at the expense of the other party by using the power of his position or knowledge (or sometimes, mental or physical power) to win acceptance of his point of view.

With regard to Compromising and Smoothing, researchers are divided. Some writers (Filley, 1975) consider them to be "Lose-Lose" strategies because neither side really accomplishes what it wants or alternately, each side only gets part of what it wants. Compromising emphasizes splitting the difference and bargaining for an intermediate position under the assumption that a half loaf is better than none. Smoothing plays down the differences between parties and emphasizes common interests. In this case, at least, one party puts more value on the maintenance of relationships with the other party than on the achievement of his own goals. However, other researchers (Burke, 1970) see some positive, or at least, neutral effects in these styles.

Finally, Avoiding is clearly a "Lose-Lose" strategy and is considered ineffective. Avoiding implies physical or mental removal of one party from a conflict situation by refraining from argument and trying not to get involved. In view of the theoretical explanations presented above, the following subhypotheses have been formulated and will be tested at the level of perception of the faculty members.

Hypothesis 1: Dean's conflict-handling modes and managerial effectiveness as perceived by faculty members are related in. the following way:

Hypothesis 1(a): Problem-Solving is significantly positively related to dean's managerial effectiveness.

Hypothesis 1(b): Forcing is significantly negatively related to dean's managerial effectiveness. 
Hypothesis 1(c): Compromising is not significantly related to dean's managerial effectiveness.

Hypothesis 1(d): Smoothing is not significantly related to dean's managerial effectiveness.

Hypothesis 1(e): Avoiding is significantly negatively related to dean's managerial effectiveness.

\section{Hypothesis 2: Relationships Between Dean's Time in Office and Dean's Mana- gerial Effectiveness}

The impact of the length of time a person has been in office on his managerial performance is not very well documented in the organizational behaviour literature. Some people argue that effectiveness increases with length of time spent in office because of the learning process going on. Others argue exactly the opposite. They claim that, in the long run, an administrator's effectiveness decreases with time simply because, after a while, he has nothing new to offer.

Bissel (1977) has tested an hypothesis relating the length of time that deans have served in their positions to their levels of performance. He established that there was a significant relationship between length of time and dean's levels of performance. The performance levels of deans who had served less than one year in their present positions were significantly higher than for deans who had served one year or more. However, in view of the lack of agreement in the literature and research, with respect to the relationship between length of time in office and managerial effectiveness, our hypothesis has been formulated in its null form.

Hypothesis 2: There is no significant relationship between the length of time deans have spent in office and their perceived managerial effectiveness.

\section{Hypothesis 3: Relationships Between Dean's Time in Office and Dean's Conflict- Handling Modes}

As in Hypothesis 2, the impact of the length of time a person has been in office on his conflict-handling modes is not clearly established. Some writers argue that a person who has been only a short period of time in his position will use unassertive modes such as Avoiding, Smoothing and to a certain extent, Compromising. Other writers take the opposite stand. A person who has been a short period of time in office will behave like a bronco using assertive modes such as Forcing and Problem-Solving. However, after a while, the socialization process going on, he tends to rely more on unassertive methods such as Avoiding and Smoothing and to a certain extent, Compromising.

Bissel (1977) also tested an hypothesis relating the length of time deans have served in their positions to their leadership characteristics. In this case, he found no significant difference between the length of time deans have served in their positions and their leadership characteristics. Again, in view of the lack of know- 
ledge with respect to the relationship between length of time in office and modes of handling conflict, our hypothesis has been formulated in its null form.

Hypothesis 3: There is no significant relationship between the length of time deans have spent in office and their self-assessed conflict-handling modes.

\section{Hypothesis 4: Relationships Between Dean's Faculty Size and Dean's Managerial Effectiveness}

This hypothesis dealing with the impact of size of the faculty on the dean's managerial effectiveness has been proposed as an exploratory hypothesis to test some commonly-expressed opinions in universities. Many deans and deans' associates believe that it is easier to manage a small faculty than a big one. In other words, deans of small faculties are perceived to be more effective than deans of large faculties. Since organizational behaviour research (for instance, Thomas and Fink, 1963) does not give a clear answer to the impact of organization size on managerial effectiveness, our hypothesis has been formulated in its null form.

Hypothesis 4: There is no significant relationship between size of faculty and dean's managerial effectiveness.

In the next section, we give a detailed description of the methodology, procedures and instruments used in the research.

\section{METHODOLOGY}

\section{Description of the Research}

The research was conducted in seven Ontario universities and was conceived as a four-stage study. Stage I involved gathering some basic information on the type of issues which academic deans perceived as important and difficult in their dealings with senior academic officers, department chairpersons and faculty members. Dimensions of effective and ineffective performance for deans were also sought at this stage. This was carried out through interviewing deans, senior academic officers, department chairpersons and faculty members in two Ontario universities: $\mathrm{U}_{\mathrm{A}}$ and $\mathrm{U}_{\mathrm{B}}$.

Stage II consisted of organizing the information collected into a meaningful framework and constructing four research instruments conceived specifically for (1) academic deans, (2) senior academic officers, (3) department chairpersons, (4) faculty members. All four instruments were pre-tested in $U_{A}$.

Stage III was the data collection by means of personal interviews in five other Ontario universities: $\mathrm{U}_{1}, \mathrm{U}_{2}, \mathrm{U}_{3}, \mathrm{U}_{4}, \mathrm{U}_{5}$. In each university, five academic deans representing major disciplines such as Arts, Social Sciences, Sciences and several professional faculties were interviewed and asked to complete a questionnaire. 
In addition, the senior academic officers to whom the deans reported were interviewed and asked to complete a questionnaire with respect to the deans' managerial performance and deans' managerial styles in certain specific conflict situations.

Stage IV involved the collection of data in the five universities mentioned above by means of a mail questionnaire sent to all department chairpersons (175) and all faculty members (2250) asking for a description of their dean's managerial performance and conflict-handling modes. The response rate was, respectively $80 \%$ and $50 \%$. We do not know why some subjects refused to cooperate in the study. As we do not have a profile of their personal and professional characteristics, we cannot make meaningful comparisons between respondents and nonrespondents.

\section{Operationalization of the Variable: Dean's Managerial Effectiveness}

Measuring the dean's managerial performance was one of the major challenges of the research. We did not get much help from the literature on higher education because it does not provide a comprehensive framework for assessing the functions and roles of the academic dean. Consequently, we turned our attention to the literature on organizational behaviour and borrowed from it a technique to assess and measure managerial effectiveness: the behaviourally anchored rating scales (BARS). This technique was operationalized by Morse and Wagner (1978) in a recent research instrument called the Managerial Effectiveness Instrument. The tool focuses on the process aspect of managerial effectiveness by defining specific behaviour a manager could be rated on to gauge the effectiveness of his performance.

The instrument was adapted for the purpose of our research and the final instrument called "Dean Managerial Performance Description" was composed of twenty (20) items clustered in six (6) major managerial categories which are:

(1) Managing the faculty's environment and its resources;

(2) organizing and coordinating;

(3) information handling inside and outside the faculty;

(4) providing for growth and development of department chairpersons and faculty members;

(5) motivating associates and conflict-handling between academics;

(6) strategic problem-solving and decision-making.

For each item of the Dean Managerial Performance Description Instrument, respondents (senior academic officers, department chairpersons, faculty members) were asked to circle the number that best represented their opinion on a fivepoint Likert scale from 0 (not at all representative of the Dean's behaviour) to 4 (to a very great extent representative of the Dean's behaviour). A global score of the dean's managerial effectiveness was obtained by adding up the scores on the 20 items. 


\section{Operationalization of the Variable: Dean's Mode of Handling Conflict}

Two instruments were used in the research for measuring the dean's modes of handling conflict: the Renwick instrument for Hypothesis 1 and the ThomasKilmann instrument for Hypothesis 3. The five conflict-handling modes identified by Blake and Mouton were operationalized by Renwick (1975) using the following statements, respectively, Avoiding, Smoothing, Compromising, Forcing and Problem-Solving.

In situations in which the Dean finds his wishes differing from those of his associates, he usually:

A. Refrains from argument, tries not to get involved.

B. Plays down the differences and emphasizes common interests.

C. Searches for an intermediate position, tries to find a compromise.

D. Uses the power of his position or knowledge to win acceptance of his point of view.

E. Brings the problem clearly into the open and carries it out to resolution, even if feelings are likely to get hurt.

Faculty members were asked, for each of the five statements to circle the number that best described their dean's behaviour using a scale from 0 (not at all representative of the Dean's behaviour) to 4 (to a very great extent representative of the Dean's behaviour). These scores were used for testing Hypothesis 1 .

The Thomas-Kilmann instrument is a self-scoring tool designed to assess an individual's style in conflict situations according to the Blake and Mouton framework (Thomas-Kilmann, 1974; Thomas, 1976). It has 30 pairs of statements describing the five conflict-handling modes, each mode being represented by 12 statements. Deans were asked to choose the statement in each pair that best described their behaviour in a conflict situation. For each dean, a profile of behaviour for handling conflict was obtained by summing up the number of statements for each mode the subject chose. These scores were used for testing Hypothesis 3 .

\section{Operationalization of the Variables: Length of Time in Office and Faculty Size}

The operationalization of the two variables, length of time in office and faculty size, posed no problem. The first one has been operationalized by the number of years the dean has served in his position and the second one by the number of faculty members included in the dean's faculty. In the next section, we will examine the main research results for each hypothesis.

\section{RESULTS AND DISCUSSION}

\section{Results for Hypothesis 1 : Conflict-Handling Modes and Managerial Effectiveness}

Hypothesis 1 relating deans' modes of handling conflict and deans' managerial effectiveness will be tested at the faculty member level. But before proceeding to 
Table 1

Spearman Correlation Coefficients Between Deans' Modes of Handling Conflict With Associates and Deans' Managerial Effectiveness as Perceived by Faculty Members

\begin{tabular}{llllll}
\hline Modes & Avoiding & Smoothing Compromising & Forcing & $\begin{array}{l}\text { Problem- } \\
\text { Solving }\end{array}$ \\
\hline $\begin{array}{l}\text { Means' } \\
\text { Managerial } \\
\text { Effectiveness }\end{array}$ & -.18 & .34 & .36 & -.13 & .39 \\
\hline
\end{tabular}

All coefficients are significant at $p<.001$

the test of Hypothesis 1, we will examine some descriptive statistics concerning the deans' modes of handling conflict with associates as perceived by faculty members. Deans are perceived to be using, in order of decreasing frequency Compromising, Smoothing, Forcing, Problem-Solving and Avoiding. A Friedman two-way analysis of variance and Wilcoxon matched-pairs signed-ranks tests indicate that each of the five modes are significantly different from the mean $(\mathrm{p}<.001)$.

After having examined these descriptive statistics, we can now turn our attention to the test of Hypothesis 1. A Spearman-rank correlation was used to investigate the relationships between conflict-handling modes and effectiveness. Table 1 shows the results of the correlation.

Hypothesis 1 has five subhypotheses, hypothesis 1(a) to hypothesis I(e), which will be discussed below.

Hypothesis 1(a) states that Problem-Solving is significantly positively related to managerial effectiveness. The correlation of .39 which is significant at $p<.001$ represents a moderately strong relationship between the two variables. We must therefore accept hypothesis 1(a). This finding supports the theory that ProblemSolving is the best way to manage conflict. And as Problem-Solving is not the most used mode of handling conflict, there is room for improvement with respect to the managerial effectiveness of deans and for university management in general.

Hypothesis 1(b) states that Forcing is significantly negatively related to managerial effectiveness. In this case, we find a small negative correlation of -.13 which is significant at $\mathrm{p}<.001$. Consequently, we must accept hypothesis 1 (b). Thus, Forcing as a dominant style of dealing with people in conflict situations should be avoided when possible. However, this researcher gathered some evidence from department chairpersons indicating that Forcing was perceived as slightly effective (in fact, the second most effective mode after Problem-Solving) in the 
following issues: budget allocation across departments $(.12, \mathrm{p}<.08)$, promotion and tenure $(.14 \mathrm{p}<.06)$, long-term goals and priorities of faculty $(.20, \mathrm{p}<.01)$. In summary, while Forcing as a dominant style of dealing with people is perceived as ineffective, Forcing as an occasional mode of dealing with difficult issues may be a convenient back-up mode to Problem-Solving because, from an organizational point of view, at least, things get done.

Hypothesis 1(c) states that Compromising is not significantly related to managerial effectiveness. The coefficient shows a moderately strong correlation of 36 , significant at $\mathrm{p}<.001$. We must therefore reject hypothesis $1(\mathrm{c})$. However, department chairpersons perceive Compromising mainly as a neutral mode of dealing with the following conflict issues: budget allocation across departments (.004, $\mathrm{p}<.48$ ), promotion and tenure $(.02, \mathrm{p}<.41)$, long-term goals and priorities of faculty $(.04, p<.30)$. In summary, although Compromising is not perceived as the most effective mode of dealing with conflict, its neutral or moderate effectiveness and relative ease of use make it the most preferred conflict-handling mode of deans.

Hypothesis 1(d) states that Smoothing is not significantly related to managerial effectiveness. The correlation coefficient of .34 which is significant at $p<.001$ suggests that hypothesis $1(d)$ should be rejected. However, department chairpersons perceive Smoothing mainly as a neutral mode (with a small negative correlation) of dealing with the following issues' budget allocation across departments $(-.03, \mathrm{p}<.38)$, promotion and tenure $(-.05, \mathrm{p}<.31)$ and long-term goals and priorities of faculty $(-.03, \mathrm{p}<.38)$. In summary; while Smoothing as a major style of dealing with people in conflict situations is easy to use and perceived as somewhat effective, it is considered, at best, a neutral model of dealing with substantive issues. Deans should keep in mind that other conflict-handling modes are more effective than Smoothing.

Hypothesis 1(e) states that Avoiding is significantly negatively related to managerial effectiveness. The coefficient of -.18 indicates a small negative relationship between the two variables which is significant at $p<.001$. We must therefore accept hypothesis 1(e). Thus, Avoiding appears as an ineffective mode of dealing with conflict and should not be used. However, the reader should keep in mind that a certain degree of Avoiding is necessary in order not to be overwhelmed by trivial issues and to be able to concentrate on important substantive issues.

\section{Results for Hypothesis 2: Time in Office and Managerial Effectiveness}

Hypothesis 2 states that there is no significant relationship between the length of time deans have spent in office and their perceived managerial effectiveness. This hypothesis will be tested at three levels of perception of deans' managerial effectiveness, i.e., (1) senior academic officer, (2) department chairperson, (3) faculty member. The results are shown below in Table 2 . 
Table 2

Spearman Correlation Coefficients Between Deans' Global Managerial Effectiveness and Length of Time in Office

\begin{tabular}{llll}
\hline $\begin{array}{l}\text { Deans' Effectiveness } \\
\text { as Perceived by: }\end{array}$ & $\begin{array}{l}\text { Senior } \\
\text { Academic } \\
\text { Officers }\end{array}$ & $\begin{array}{l}\text { Department } \\
\text { Chairpersans }\end{array}$ & $\begin{array}{l}\text { Faculty } \\
\text { Members }\end{array}$ \\
\hline $\begin{array}{l}\text { Length of Time in } \\
\text { Office (in Years) }\end{array}$ & $\begin{array}{l}-.38 \\
(N=25, S=.03)\end{array}$ & $\begin{array}{l}-.31 \\
(N=20, S=.10)\end{array}$ & $\begin{array}{l}-.19 \\
(N=19, S=.22)\end{array}$ \\
\hline
\end{tabular}

All three correlation coefficients are negative. There is a moderately strong negative correlation between length of time in office and deans' effectiveness as seen by senior academic officers of -.38 , significant at $p<.03$ level. Similarly, department chairpersons perceive a moderate negative correlation of -.31 which is significant at $\mathrm{p}<.10$ level. Finally, faculty members also perceive a negative correlation of -.19 but it does not reach acceptable levels of significance $(p<.22)$. Consequently, we must reject Hypothesis 2 and conclude that there is, indeed, a moderate negative relationship between managerial effectiveness and length of time in office.

This finding may have several important implications regarding first, the length of term for which deans should be appointed and second, the appointment of deans for a second or third mandate. Furthermore, the findings seem to add credibility to two popular theories of deanship (1) the "chips" theory (2) and the "honeymoon" theory. The "chips" theory says that a dean starts with a bag full of chips which represent power, influence, authority and people's goodwill. During his term, the dean has to spend his chips and has no way to get new ones. So if everything goes well, he finishes his term with, at best, an empty bag. The "honeymoon" theory is similar to the first one. A dean at the beginning of his term benefits from a "honeymoon effect" with respect to his faculty and chairpersons. As a new dean, he has people's confidence and goodwill but as time passes he has to make unpopular decisions and consequently his prestige and effectiveness decline during his term in office.

\section{Results for Hypothesis 3: Time in Office and Conflict-Handling Modes}

Hypothesis 3 states that there is no significant relationship between the length of time deans have spent in office and their self-assessed conflict-handling modes. Table 3 shows the correlation coefficients between length of time deans have spent in office and their self-assessed modes of handling conflict.

One of the most interesting findings is the strong correlation of 46 (significant at $p<.01$ ) between Smoothing and years in office. The longer a dean has been in office, the more he sees himself as a Smoother, that is as someone who plays 
Table 3

Spearman Correlation Coefficients Between Deans' Self-Assessed Modes of Handling Conflict and Length of Time in office $(N=25)$

\begin{tabular}{|c|c|c|c|c|c|}
\hline Modes & Avoiding & Smoothing & Compromising & Forcing & $\begin{array}{l}\text { Problem- } \\
\text { Solving }\end{array}$ \\
\hline $\begin{array}{l}\text { Length of } \\
\text { of Time in } \\
\text { Office (in } \\
\text { Years) }\end{array}$ & $\begin{array}{l}10 \\
(S=.32)\end{array}$ & $\begin{array}{l}.46 \\
(S=.01)\end{array}$ & $\begin{array}{l}-.23 \\
(S=.14)\end{array}$ & $\begin{array}{l}-.02 \\
(5=.46)\end{array}$ & $\begin{array}{l}-.27 \\
(S=.10)\end{array}$ \\
\hline
\end{tabular}

down the differences and emphasizes common interests. Of course, the direction of the relationship could easily be reversed. The more a dean uses Smoothing as a conflict-handling mode, the longer he will stay in office. In any case, Smoothing which is a cooperative and unassertive mode seems to be the key to longevity. Another interesting finding is the moderate negative correlation of -.27 (significant at $p<.10$ ) between Problem-Solving and years in office. The longer a dean stays in office, the less likely he is to see himself as a Problem-Solver. ProblemSolving which is an assertive and cooperative mode appears to be a difficult conflict-handling mode to use over a long period of time.

Compromising is another interesting finding to look at. There is a negative correlation of -.23 between this mode and years in office (but significant only at $p<.14$ ). The longer a dean stays in office, the less he sees himself as a compromiser. Compromising which is moderately assertive and moderately cooperative also appears to be a difficult mode to use over a long period of time. Finally, there is no significant relationship between length of time in office and Avoiding and Forcing. The coefficients are respectively of .10 (significant at $\mathrm{p}<.32$ ) and -.02 (significant at $\mathrm{p}<.46$ ). In summary, we must accept Hypothesis 3 for Avoiding, Forcing and Compromising and reject it for Smoothing and ProblemSolving.

\section{Results for Hypothesis 4: Faculty Size and Managerial Effectiveness}

Hypothesis 4 states that there is no significant relationship between size of faculty and deans' managerial effectiveness. This hypothesis was included in the research in order to test a proposition which was frequently put forward during the field interviews by senior academic officers and deans themselves. The theory is that it is easier to manage a small faculty than a big one. In other words, deans of smaller faculties would be perceived to be more effective than deans of bigger faculties. As mentioned previously in this article, the variable faculty size was operationalized by the number of faculty members included in the dean's faculty. The hypothesis will be tested at three levels of perception of dean's managerial 
Table 4

Spearman Correlation Coefficients Between Deans'

Managerial Effectiveness and Faculty Size

\begin{tabular}{llll}
\hline $\begin{array}{l}\text { Deans' Managerial } \\
\text { Effectiveness } \\
\text { as Perceived by: }\end{array}$ & $\begin{array}{l}\text { Senior Academic } \\
\text { Officers }\end{array}$ & $\begin{array}{l}\text { Department } \\
\text { Chairpersons }\end{array}$ & $\begin{array}{l}\text { Faculty } \\
\text { Members }\end{array}$ \\
\hline $\begin{array}{l}\text { Number of } \\
\text { Faculty Members }\end{array}$ & $\begin{array}{l}.24 \\
(S=.13, N=25)\end{array}$ & $\begin{array}{l}.33 \\
(S=.08, N=20)\end{array}$ & $\begin{array}{l}.49 \\
(S=.02, N=19)\end{array}$ \\
\hline
\end{tabular}

effectiveness: (1) senior academic officer, (2) department chairperson, (3) faculty member. Table 4 presents the results of the Spearman correlation between faculty size and dean's managerial effectiveness.

Senior academic officers perceive a positive correlation between faculty size and deans' managerial effectiveness of $.24(\mathrm{p}<.13)$. Department chairpersons perceive a moderately strong positive correlation of $.33(\mathrm{p}<.08)$. Finally, faculty members perceive a strong positive correlation of $.49(\mathrm{p}<.02)$ between the two variables. In conclusion, we must reject Hypothesis 4 as a whole. There is a significant positive relationship between size and deans' effectiveness. In other words, deans of larger faculties are perceived to be more effective than deans of smaller faculties. Obviously, this finding goes contrary to the beliefs expressed during the field interviews by senior academic officers and deans themselves.

Three explanations are offered to clarify this point. The first one is that deans of large faculties are indeed more effective than deans of smaller faculties, partly because it is easier to find excellent candidates for deanship in large faculties than in small ones. The second possible explanation is that the raters (senior academic officers, department chairpersons, faculty members) are more liberal in their ratings of deans of large faculties because the deans' job appears to be more difficult, and more conservative in their ratings of deans of small faculties because the deans' job appears to be easier. Finally, the third explanation is simply that, from a department chairperson's and faculty member's point of view, "the more you see and know the dean, the less effective he seems".

\section{CONCLUSIONS AND IMPLICATIONS}

\section{The Managerial Aspects of the Dean's Job}

The purpose of the study was to investigate the managerial aspects of the academic deanship and to find correlates of effective performance for a dean. We indeed found that the managerial aspects of the dean's job are very important. All the managerial dimensions identified in the Dean Managerial Performance Description 
Instrument were directly or indirectly validated through the interviews of deans and senior academic officers and through the written comments of department chairpersons and faculty members.

Furthermore, the managerial effectiveness of a dean is very much dependent on some of his personal characteristics and behaviours, especially his modes of handling conflict. The leadership characteristics of the dean and his ability to deal with people in conflict situations are of paramount importance. Inability to lead, and poor management of interpersonal and organizational conflict can wreck a deanship. Consequently, the dean should be aware of his conflict-handling modes and he should know how to behave depending upon the situation.

\section{Measuring Effectiveness in Higher Education}

Although a majority of respondents fully cooperated in the study, this researcher must admit that measuring managerial effectiveness was not an easy task. Some people resented the fact that management concepts and models were applied to academe. As one respondent wrote: "The last person I would want to see as the Dean of my faculty is somebody trained in management skills. I feel strongly that the ethos of a university as such is radically different from that which should obtain in a business organization. What makes for efficiency in the one does not necessarily make for efficiency in the other". However, the uneasiness of these academics in applying management models to the dean's job must be put in the broader context of assessing effectiveness in higher education.

Cameron (1978) in a study on university effectiveness noticed that "the evaluation of institutional effectiveness engenders skepticism and defensiveness in the academic community. Calls for evaluations of effectiveness or institutional accountability are seen as the public trying to scrutinize and control higher education, or as the existence of defects that need to be corrected." As in Cameron's research, we got the same remarks from skeptical academics who claimed that "uniqueness" should prevent universities from being evaluated.

Evaluation of effectiveness of people and institutions in higher education is often seen as a potential threat to academic freedom and at best as useless. Cameron states that the following report on an administrator's position on evaluation is illustrative of the approach taken by many administrators in higher education: "This evaluation will be a waste of time, for either it will demonstrate that the program is excellent or that it is defective in some sense. In the first case, it is a waste of time because we already know that it's a good program, and in the second, it's a waste of time because we would not believe any evidence of weakness". In spite of the skepticism and defensiveness shown by some academics in the research, we feel that this study was able to demonstrate the relevance of applying managerial concepts to the dean's job.

A number of implications for the academic deanship and the management of universities are derived from our research findings. They deal with administrative practice, the selection and the educational preparation of deans as well as the ongoing management of universities. 


\section{Implications for the Practice of Deans}

Our study suggests that deans should pay attention to the managerial roles involved in their job. As noted earlier, these roles deal with (1) managing the faculty's environment and its financial and human resources, (2) organizing and coordinating the tasks of the departments, (3) information handling inside and outside his faculty, (4) providing for growth and development of department chairpersons and faculty members, (5) motivating associates and conflict-handling between academics and (6) strategic problem-solving and decision-making.

Deans should keep in mind that it is difficult to be perceived as effective in the long run. In times when unpopular decisions are often required, it is likely that their managerial effectiveness will be seen as decreasing as time passes. Consequently, deans should develop their capacity to cope with stress and frustration because they may not get much encouragement from their associates in their deanship. Our findings also demonstrate that deans of large faculties benefit from a favorable bias: they are seen to be more effective than deans of small faculties. Consequently, deans of large faculties should fully capitalize on the prestige of their office and the size of their unit.

Our study also shows that the conflict-handling mode is a major contributor to the perceived administrative effectiveness of deans. Consequently, deans appointed to office should pay greater attention to the way they handle difficult issues and deal with associates. In dealing with substantive conflicts, deans should rely more on Problem-Solving than on Compromising because the first mode is perceived as more effective. On certain occasions, they should not be afraid of using Forcing for resolving certain substantive issues. Finally, if Problem-Solving and Forcing are too difficult to use (i.e., in terms of energy and time), deans should remember that Compromising is perceived as a convenient and slightly effective mode to use. Smoothing and especially Avoiding should not be used by deans for dealing with substantive issues. Smoothing is perceived, at best, as a neutral mode and Avoiding is perceived as very ineffective.

Deans should be aware that Problem-Solving and, to a certain degree, Compromising are modes which are difficult to maintain in the long run. Deans whose objective is to stay in office for a long period of time (i.e., several mandates) should mainly rely on Smoothing. Accommodating tactics and behaviours avoid making enemies and thus insure longevity in office.

\section{Implications for the Selection of Deans}

A number of implications for the selection of deans emerge from this research. First, candidates who are aware and comprehend the managerial dimensions of the dean's job should be given preference over those who conceptualize the dean's job as a purely academic position. The Dean Managerial Performance Description Instrument used in this research identifies six main managerial categories which people involved in the selection process should consider.

Second, conflict-handling modes should be important criteria in the selection 
process. Deans will have to face an uncertain future in which tensions in the areas of financing and personnel will lead to increasing conflicts. In this context, conflictmanagement skills will be a major asset for academic deans. People involved in the selection process should accept that fact and think about ways in which conflict-handling modes might be assessed. Certainly, the reputation and the past experience of the candidates should be of great help in this respect. The ThomasKilmann instrument and the Renwick instrument may also offer more systematic ways of assessing modes of handling conflict. Our research findings suggest that the deans who are perceived to be the most effective are Problem-Solvers and Compromisers in that order. Smoothers who are perceived to be nice deans may not be very effective. Forcers are not perceived to be effective because they tend to alienate everybody in the system. Finally, Avoiders should not be deans because their deanship may lead the system to chaos by paralysis.

Third, people involved in the selection process of deans should be careful about giving a second or a third mandate to a dean. Our research findings suggest that perceived managerial effectiveness decreases with the time spent in office.

\section{Implications for the Educational Preparation of Deans}

This study established or confirmed the relevance of applying some management concepts and models to universities. We feel that it adds legitimacy and credibility to the programs and bodies involved in the managerial education of academic administrators such as the Senior University Administrators' Course at the University of Western Ontario and the Institute for Educational Management at Harvard University. It should encourage deans themselves and other senior academic officers to participate in such management programs. This research also offered some evidence showing that the conflict-management skills of an important university administrator (i.e., the dean) was perceived as a major contributor to his administrative effectiveness. This finding is of a great interest for the people involved in the teaching of organizational behaviour in educational programs. Empirical support concerning the use and effectiveness of modes of handling conflict has also been provided which can add some prescriptive sophistication to the teaching of organizational behaviour in these management programs.

\section{Implications for the On-Going Management of Universities}

This study showed that not only conflict-handling modes were a major contributor to perceived managerial effectiveness but also, and perhaps more important, that management concepts and models had some relevance and use in universities. To the extent that the findings of this study can be generalized, these research results should be useful to other people involved in university management such as senior academic officers, department chairpersons and faculty members, with respect to their own administrative practices and their dealings with academic deans. Ultimately, improved personal effectiveness for these keypeople should result in increased organizational effectiveness and efficiency for universities. 


\section{FOOTNOTE}

1. This article is based on the author's doctoral dissertation completed at the University of Western Ontario (see Garnier, 1980). The author wishes to thank the members of his dissertation committee: J.J. DiStefano, D.A. Peach and J. Gandz for their valuable suggestions and encouragements in this research. He gratefully acknowledges the helpful comments on this article from Y. Gasse, J. Grisé, J. Petrof and anonymous CJHE reviewers.

\section{REFERENCES}

Bissel, H.L. The relationship of leadership characteristics of academic deans in seventh-day adventist colleges and universities to their performance levels as perceived by educational administrators and faculties. Unpublished doctoral dissertation. Andrews University, 1977.

Blake, R.R., \& Mouton, J.S. The managerial grid. Houston: Gulf Publishing Company, 1964.

Burke, R.J. Methods of resolving superior-subordinate conflict: The constructive use of subordinate differences and disagreements. Organizational Behavior and Human Performance, 1970, 5, 393-411.

Cameron, K. Measuring organizational effectiveness in institutions of higher education. Administrative Science Quarterly, 1978, 23, 604-632.

Filley, A.C. Interpersonal conflict resolution. Glenview, Illinois: Scott Foresman and Company, 1975.

Garnier, B. The impact of conflict-handling modes of academic deans on their perceived managerial effectiveness: an empirical study in selected Canadian universities. Unpublished doctoral dissertation. The University of Western Ontario, 1980.

Konrad, A.G. Deans in Canadian higher education. The Canadian Journal of Higher Education, 1980, $10(2), 53-72$.

Lawrence, P.R., \& Lorsch, J.W. Organization and environment. Homewood, Illinois: Richard D. Irwin, 1969.

Morse, J.J., \& Wagner, F.R. Measuring the process of managerial effectiveness. Academy of Management Joumal, 1978, 21(1), 23-35.

Renwick, P.A. Perception and management of superior-subordinate conflict. Organizational Behavior and Human Performance, 1975, 13, 444-456.

Thomas, E.J., \& Fink, C.F. Effects of group size. Psychological Bulletin, 1963, 60(4), 371-384.

Thomas, K.W., \& Kilmann, R.H. Thomas-Kilmann conflict mode instrument. New York: Xicom Inc., 1974.

Thomas, K.W. Conflict and conflict management. In M.D. Dunnette (Ed.), Handbook of industrial and organizational psychology. Chicago: Rand McNally, 1976. 